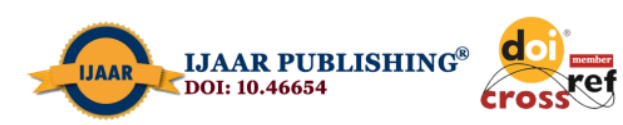

International Journal of Advanced Academic Research (Social and Management Sciences) | ISSN: 2488-9849 Vol. 6, Issue 10 (October, 2020) | www.ijaar.org

Journal DOI: 10.46654/ij.24889849

Article DOI: 10.46654/ij.24889849.s6107

\title{
EFFECT OF BIG DATA ON THE QUALITY OF AUDIT REPORTS IN ANAMBRA STATE
}

\author{
Nwadialor, E.O and Obi, Theresa Nwadi \\ Department of Accountancy, \\ Faculty of Management Sciences, \\ Chukwuemeka Odumegwu Ojukwu University, Igbariam Campus, \\ Anambra State, Nigeria. \\ Emails: profnwadialor@gmail.com and theresaobi2@gmail.com
}

\begin{abstract}
This research work is on the effect of big data on the quality of audit reports in Anambra State. The following three specific objectives were considered; to determine the effect of volume of data collected on the sufficiency of the audit reports in Anambra State, secondly, to evaluate the effect of frequency of data collected on the timeliness of audit reports in Anambra State, thirdly, to ascertain the effect of value of data collected on the verifiability of the audit reports in Anambra State. Survey research design, descriptive statistics and correlation matrix were employed alongside the pooled Ordinary Least Square (OLS) regression in analyzing the data and testing of hypotheses. The findings of the study from the three models tested were that; Volume of Data Collection (VDC) has a positive effect on the sufficiency, timeliness and verifiability of audit reports but had positive insignificant effect on the sufficiency of audit reports. Secondly, Frequency of Data Collection (FDC) has a positive significant effect on the sufficiency, timeliness and verifiability of audit reports and finally, Value of Data Collection (VALDC) has negative significant effect on the verifiability but have a positive insignificant effect on the sufficiency and timeliness of audit reports in Anambra State. The researcher recommends that: Auditor-General's Offices and Auditing firms that wish to improve on the quality of their audit report through the use of big data collection, measured as Volume of Data Collected(VDC) and Frequency of Data Collection (FDC) in Anambra State should adopt sufficiency, timeliness and verifiability of audit reports as they have positive and significant influence on audit reports and may choose to ignore sufficiency of audit reports as though it has a positive effect but the effect is not statistically significant. Finally, for those that want to improve on the quality of their audit reports through the use of big data measured as Value of Data Collection (VALDC) in Anambra State, they may choose to ignore the use of sufficiency and verifiability of audit report as they were found to have a positive influence but this influence was statistically insignificant but should concentrate more on ensuring that they maintain good timeliness of audit reports as it has a negative significant effect on the quality of audit reports.
\end{abstract}

Keywords: Big Data, Quality Audit Reports, Volume of data, Frequency of data, and Value of data. 


\section{INTRODUCTION}

In today's business environment characterized by constant disruption, slow growth and uncertainty, organizational boards have faced more challenges than ever in creating a riskaware corporate culture and establishing sound risk governance and controls. The risk associated with corporate failures has been observed to be related to the volume of transactions handled by many organizations which is also known as "big data" (Sharma, 2015). For many organizations, embracing big data is crucial to keeping their organization nimble, competitive and profitable. To ascertain the performance of corporate organizations in the era of big data, AB Magazine (2015) noted that big data is transforming the way audits are conducted but also posing a major challenge to existing standards and training as well as systems and processes. Big data is also a relative concept if one wishes to qualify it. A set of data can be said to be big if the information system is either at its maximum capacity or cannot accomplish the task (Accounting Horizons, June 2015). Some authors like Dijcks (2012) and Dumbill (2013) described big data on the basis of volume, velocity, variety, veracity, valence and value of data collected. The big data movement, like analytics seeks to glean intelligence from data and translate that into business advantage.

As of 2012, about 2.5 Exabyte of data (volume) were created each day and that number is doubling every 40 months. More data cross the internet every second than are stored in the entire internet just 20 years ago. This gives companies an opportunity to work with many petabytes of data in a single data set and not just from the internet. Example, it is estimated that Walmart collects more than 2.5 petabytes of data every hour from its customer transactions. A petabyte is one quadrillion bytes or the equivalent of about 20 million filing cabinets worth of text. An Exabyte is 1000 times that amount or one billion gigabytes (McAfee and Brynjolfsson, 2012). Presently in Nigeria, Federal Inland Revenue Service is calling on Nigerian Custom Service and other revenue generating MDAs to give them access to their big data to aid them in their tax assessments to boost government revenue.

PCAOB (2004) has also insisted that auditors should test the completeness (sufficiency) and accuracy of the data presented to them to determine the degree of reliance to be placed on the audit evidence before them and entire body of data not samples of transaction data. According to Adeniyi (2004), an auditor should obtain sufficient appropriate audit evidence to be able to draw reasonable conclusions on which to base the opinion in order to arrive at quality audit reporting. That appropriateness (the quality of evidence) is achieved if the evidence obtained is relevant and reliable. The audit evidence should be sufficiently documented so as to use them before issuing auditor's report. The quality of completeness ensures that users are given a round picture of the economic activities of the firm.

For many applications, the speed of data creation is even more important than the volume. Real-time or nearly real time information (frequency) makes it possible for a company to be more agile than its competitors (McAfee and Brynjolfsson, 2012). If data on customer satisfaction can be continuously collected and analyzed from worldwide social media and platforms, a company or agency can have more reliable and timely evidence to identify usual bottlenecks, understand customer behavior and improve performance (Netflix (2013).Such frequency of data generation, filtering and retention decisions are the basis on the predicted potential value of more frequent information.

Big data (value) is anticipated to make important contributions in the audit field. It is useful to external auditors by enhancing the quality of audit evidence and facilitating fraud detecting 
(Yoon, Lucas and $\mathrm{Li}, 2015$ ) 'One of the most useful potential uses of big data is its ability to provide a population based audits, the results of which should generate more relevant audit evidence'. Additional big data can provide more solid verification. In short, auditors should first identify potentially relevant and useful data, then collect and merge data.

Whitehouse (2014) further posited that, auditors of present times were made to demand for all the transaction documents whether it is in millions, tens of millions or in tens of thousands as the case may be. Despite the volume, value, valence, variety and velocity of data to be audited, the auditor is expected in this era of big data to conduct $100 \%$ intensive vouching/auditing not by way of sampling as some Auditors do in the traditional approach of auditing but with advanced technologies. Auditing standards require auditors to plan and perform audits to obtain reasonable assurance about whether the financial statements are free of material misstatements and to express an opinion about the fair presentation of the financial statements (PCAOB 2010). The degree to which financial statement users can rely on an audit report depends on the quality of the audit performed. The high quality audit report will provide additional value to the financial statement that is stated in the financial report, in which investors utilizing this information for decision making uses (Salleh \& Jasmani, 2014). The undeniable effect, big data will have on Nigerian economy and specifically on Anambra State economy led the researcher to determine the effect of big data on the quality of audit reports in Anambra state.

For some time now, audits were conducted using samples of big data which has called for criticisms on the quality of audit reports. In particular, regulators have often expressed their concern that the volume of data could impair the quality of auditor's report. Auditors express their audit opinions on a financial statement presented to them based on audit evidence (Davis, Soo \& Trompeter, 2003). Public Company Accounting Oversight Board (PCAOB) (2004) said, firms need to invest in technology and analytics so as to change in the way we conduct audits. Ferguson, Francis, Stockes (2006) further said that, "Auditing standards need some revision to facilitate the use of more advanced technology that will overtake traditional sampling techniques that is undesirable and awkward to ensure that our present standards are not forcing Auditors to do things that have been overtaken and are irrelevant, thereby compromising and not having a thorough, quality and more efficient audit”.

Previous empirical studies relating to this research work made the following findings: Jafar Raza Alem, Asma Sajid, Ramzan Talib,Muneeb Niaz (2014) found out that; organizations report that the use of big data is beneficial for their companies and organizations; that customer and product data are used for business decision making and that $3.12 \%$ organizations are implementing the big data strategy and $71 \%$ organizations are going to begin planning stage. Frank Danielsen and Augustine Franes (2017) and Canchu Lin (2016) respectively, argued that, "There is a positive correlation between big data analytics, capabilities and dynamic capabilities to competitive performance; the path from dynamic capabilities to competitive performance is significant; that there is a positive correlation between big data analytics capabilities and operational performance; there is a positive correlation between operational capabilities and competitive performance". Uthayasankar Sivarajah, Muhammed Mustapha Kamal, Zahir Irani, Weerakkody Vishant (2017); their result show that; "Big data had contributed to both conceptually and empirically to the expansion and accrual of intellectual wealth of big data analytics in technology or organizational resources management discipline". Nataliia Shalimuva and Zoyo Stezhko (2016), their result shows that; " The application of proposed qualitative characteristics 
enables auditors reports, taking into account, information requirements of users and increasing the audit effectiveness that will lead to the quality of audit as a communication process" Mohamed Abulgasem Zakari (2013\} found out that; "Evidence type of audit evidence has an impact on auditor's report" Augustine et al (2013), found out that; "Sufficiency of audit evidence has a negative coefficient but insignificant impact on audit reports while the reliability of audit evidence has a positive coefficient sign but insignificant. Akram Niktaba \& Azim Aslani (2015), found out that; "Sufficient audit evidence has significant effect on audit report and can modify the audit report". Jared D. Cline (2016) in his findings showed that; "the more accounts are labeled as risky, the higher the performance and there is a significant relationship between information overload and Auditor-mindset and there is no significant relationship between confidence level, increased calibration and auditor mindset". Nyor, Terzungwe (2013), found out that, "the annual reports and accounts of Nigerian firms is adjudged to be moderate by users of accounting information in Nigeria". Idil Kaya, Destan Halit Akbulut (2018), found out that; "The nature of accounting and financial reporting do not alter but traditional method of recording, collecting and analyzing accounting information changed and that the revenue recognition in many industries including airways and telecommunication companies need to process large volume of data because of the complex billing system. That Big data analytics also presents a pressing issue and real opportunity for accountants working in forensic and valuation areas".

Considering the present need for $100 \%$ vouching of government financial transactions and also the quality of audit report of Nigerian government bedeviled with corrupt practices, the unending failure of audited accounts of ministries, departments and agencies in Nigeria has called to the quality of audit reports most especially as it involves large transactions. The researcher therefore seeks to determine 'the effect of big data on the quality of audit reports in Anambra State'.

The study is to determine the effect of big data on the quality of audit reports in Anambra State. The following specific objectives will guide this study:

1. To investigate the effect of volume of data collected on the quality of audit reports in Anambra State.

2. To evaluate the effect of frequency of data collected on the quality of audit reports in Anambra State.

3. To ascertain the effect of value of data collected on the quality of audit reports in Anambra State.

\section{REVIEW OF RELATED LITERATURE Volume of Data Collection:}

According to George, Osinga, Lavie, Scott (2016), volume of data: is the 'newness' of data that decision makers are able to collect, representing the sheer size of the dataset due to the aggregation of a large number of variables and an even larger set of observations for each variable. Kaplan and Haenlein (2019) defined volume of data as data sets characterized by huge quantity of data (volume).

According to Kitchin, Rob, McArdle, Gavin (2016), volume of data is the quantity of generated data and stored data. The size of the data determines the value and potential insight, and whether it can be considered big data or not. Akter, Wamba, Gunasekaran, Dubey, Childe (2016a) opined it that, many definitions highlight the growing rate at which 
the quantity of data increases, commonly expressed in petabytes or exabytes, used by decision makers to aid strategic decisions.

\section{Frequency (Volume) of Data Collection:}

According to (George et al.2016), Velocity(frequency) of data: Is the speed at which data are collected and analyzed, whether in real time or near real time from sensors, sales transactions, social media posts, and sentiment data for breaking news and social trends.

Velocity in data collection is frequently updated data (Frequency) (Kaplan, Andreas; Haenlein, Michael (2019). According to Kitchin et al (2016), Velocity (frequency) of data in this context, is the speed at which the data is generated and processed to meet the demands and challenges that lie in the path of growth and development. Big data is often available in real-time. Compared to small data, big data are produced more continually. Two kinds of velocity related to big data are the frequency of generation and the frequency of handling, recording, and publishing. According to (Davis 2014; George et al.2016), Velocity shows the speed at which these data were collected, updated, and analyzed, as well as the rate at which their value becomes obsolete. High velocity refers to the high rate of data generation, also known as the data stream. Data streams must be processed in a real-time or near real-time manner (Chen \& Zhang 2014).

\section{Value of Data Collection:}

According to Wamba, Akter, Edwards, Chopin, Gnanzou (2015) Value of data shows the extent to which big data generates economically, worthy insights and/or benefits through extraction and transformation. Value: Extracting knowledge/value from vast amounts of structured and unstructured data without loss, for end users. Significant values can be extracted from the stream of clicks left behind by the internet users - and this is becoming a backbone of the internet economy. Big data researchers consider value as an essential feature, as somewhere within that data, there is valuable information - extracting golden data (highvalued data), though most of the pieces of data independently may seem insignificant (Zaslavsky, Perera, \& Georgakopoulos, 2012).

Regardless of where big data is generated from and shared to, with the reality of big data comes the challenge of analyzing it in a way that brings Big Value. With so much value residing inside, big data has been regarded as today's Digital Oil (Yi, Liu, Liu, \& Jin, 2014) including the New Raw Material of the $21^{\text {st }}$ century. The potential value of big data is solved simply when leveraged to the drive decision-making process. Extant research studies have demonstrated that substantial value and competitive advantage can be attained by businesses from taking effective decisions based on value data (Davenport \& Harris, 2007).

\section{Quality of Audit Reports}

Ferguson et al (2006) further said, that auditing standards need some revision to facilitate the use of more advance technology that will overtake traditional sampling techniques, undesirable and awkward methods to ensure that our present standards are not forcing Auditors to do things that had been overtaken and are irrelevant, thereby compromising and not having a thorough, better quality and more efficient audit. Audit quality as defined by in Rajgopal, Srinivasan, and Zheng (2015) is the joint probability that auditors discover a breach in the client's accounting system, and report the breach. 
According to Gray, Turner, Coram \& Mock (2011), in recent times, quality audit reports have been used in securing investors, shareholder and stakeholders' interest and confidence. However, the extent to which this statement is true and effective has continued to raise some concerns for investors and scholars. Also according to (Francis, 2004), the issue of quality audit report has been one of the major concerns of investors, shareholders and stakeholders as well as key considerations for auditors across the globe. Audit as a profession was argued to have suffered a lot because it is believed to be the pancreas that cures all ills. For example, executing high quality audit task implies reduced audit risk and minimal chances of issuing biased audit opinion.

According to Hoag, Myring, \& Schroeder (2017), opined it that audit practitioners and scholars had devoted attention on improving public confidence via close calls in devising means of enhancing the quality of audit reports produced. Auditing standards require auditors to plan and perform audits to obtain reasonable assurance about whether the financial statements are free of material misstatements and to express an opinion about the fair presentation of the financial statements (PCAOB 2010). The degree to which financial statement users can rely on an audit report depends on the quality of the audit performed. The high quality audit report will provide additional value to the financial statement that is stated in the financial report, in which investors utilizing this information for decision making (Salleh and Jasmani, 2014).

Many third-party users prefer, or even require financial information to be certified by an independent external auditor, many auditees rely on audit reports to certify their information in order to attract investors, obtain loans, and improve their public appearance. Some have even stated that financial information without quality auditor's report is essentially worthless for investing purposes (Christense (2016). It is important to note that auditor's reports on financial statements are neither evaluations nor any other similar determination used to evaluate entities in order to make a decision. The report is only an opinion on whether the information presented is correct and free from material misstatements, whereas all other determinations are left for the user to decide (Christensen (2016). Weak audit quality has resulted in unexpected collapse of high-profile companies such as WorldCom, One-Tel, Enron and Harris Scarfe. These scandals have led investors, regulators, general public, and the academician to pay their attention to consider audit quality, to identify the underlying causes of loss of quality audit and to develop and improve audit quality (Al-sraheen, 2014).

\section{Empirical Studies:}

Jafar Raza Alem, Asma Sajid, Ramzan Talib,Muneeb Niaz (2014) did, “ A review on the role of big data in business and concluded that, organizations reports that the use of big data is beneficial for their companies and organizations 2. Customer and product data are used for business decision making. 3. 12\% organizations are implementing the big data strategy and $71 \%$ organizations are going to begin planning stage. Frank Danielsen and Augustine Franes (2017) worked on, "Towards an understanding of big data analytics as a weapon for competitive performance and found out that. "There is a positive correlation between big data analytics, capabilities and dynamic capabilities to competitive performance. 2 . The path from dynamic capabilities to competitive performance is significant. 3 . That there is a positive correlation between big data analytics capabilities and operational performance. 4 . There is a positive correlation between operational capabilities and competitive performance. Canchu Lin (2016) studied on, "Exploring big data capability: Drivers and Impact on Supply Chain Performance" and found out that, "Technology orientation facilitates the development of big 
data capability. 2. Developmental culture negatively moderates the relationship between technology orientation and the development of big data. 3. Big data capability positively impacts firm's performance in new product development by enhancing their knowledge management process. 4. Relationship building, positively moderates that process and dynamic capabilities to competitive performance. 2 . The path from dynamic capabilities to competi. Uthayasankar Sivarajah, Muhammed Mustapha Kamal, Zahir Irani, Weerakkody Vishant. (2017) researched on, "Critical analysis of big data, challenges and analytical methods" and their results show that, "Big data had contributed to both conceptually and empirically to the expansion and accrual of intellectual wealth of big data analytics in technology or organizational resources management discipline". Nataliia Shalimuva and Zoyo Stezhko (2016), researched on "Qualitative characteristics of the auditor's reports" and concluded that "The application of proposed qualitative characteristics enables auditors reports, taking into account, information requirements of users and increasing the audit effectiveness that will lead to the quality of audit as a communication process". Mohamed Abulgasem Zakari (2013) "investigated the extent of sufficiency and appropriateness of audit evidence obtained by auditors in the Libyan context" and his result shows that evidence type has an impact on auditor's report. Augustine et al (2013) "Evaluated the impact of sufficient audit evidence on audit report and also investigated the influence of reliability of audit evidence on audit report" and found out that, "Sufficiency of audit evidence has a negative coefficient but insignificant impact on audit reports while the reliability of audit evidence has a positive coefficient sign but insignificant". Akram Niktaba \& Azim Aslani (2015) studied on "How much is enough audit evidence effective on the auditor's reports? And is there any relationship between the audit evidence and auditor's report? And found out that, "Sufficient audit evidence has significant effect on audit report and can modify the audit report". Jared D. Cline (2016), studied on the data mindset and its effects on auditor performance" and their findings shows that "The more accounts are labelled as risky, the higher the performance and that there is a significant relationship between information overload and Auditor-Mindset. There is also no significant relationship between confidence level, increased calibration and auditor mindset. Nyor, Terzungwe (2013) studied on, "Financial reporting quality of Nigerian firms" and found out that, "The annual reports and accounts of Nigerian firms is adjudged to be moderate by users of accounting information in Nigeria. Idil Kaya, Destan Halit Akbulut (2018) studied on "Big data analytics in financial reporting and accountability within the institutional framework through the participants' perception" and found out that, "The nature of accounting and financial reporting do not alter but traditional method of recording, collecting and analysing accounting information changed. The revenue recognition in many industries including airways and telecommunication companies need to process large volume of data because of the complex billing system. Big data analytics presents a pressing issue and real opportunity for accountants working in forensic and valuation areas. Ricci \& Kalyva (2015) dealt with unlocking the full potential of big data and concluded that decision makers should change their mindset from traditional decision making process to a data driven approach and that corporate culture should be focused between data specialist and decision makers that collaborate and exchange knowledge.

\section{Gaps In Literature Reviewed:}

- There is gap in location: Most related works were done abroad.

- There is gap in independent variables proxies and dependent variables proxies.

- There is gap in industry: Most works were done in private sector but this work focuses more on public sector (MDA's) than private sector auditing. 
- There is gap in population/sample: This work focuses on public sector external auditors and few statutory private auditors registered with Office of the Auditor-General for State.

- There is gap in title: Effect of big data on the quality of audit reports in Anambra State.

\section{RESEARCH METHODOLOGY}

The researcher adopted the use of survey research design. This design will enhance the researcher to gather opinions on the effect of big data on the quality of audit reports in Anambra State.

The population for the study was the 210 external auditors in Anambra State Government who do audit of their Ministries, Departments and Agencies (MDAs). The external auditors in Anambra State include: 33 auditors from 11 registered audit firms with Anambra State Office of the State Auditor General. While the external auditors are 54 auditors with Anambra State Local Government Audit Office and 123 Auditors with Anambra State Auditor General's Office.

The sample size for the study is 81 . In determining the sample size, the researcher used Alien Taro Yamane (1967) method of sample size determination. Yamane (1967) provides a simplified formula to calculate sample size. This formula was used to calculate the sample size for this study and is shown below. A 92\% confidence level (for this present study). The formula for the sample size estimation is given as:

$$
\mathrm{N}=\frac{\mathrm{N}}{1+\mathrm{N}(\mathrm{e})^{2}}
$$

Where:

$\mathrm{n}=$ the sample size

$\mathrm{N}=$ the population size

$\mathrm{E}=$ the level of precision (allowable error) that is $8 \%$ or 0.08

Therefore, the sample size estimation is given as:

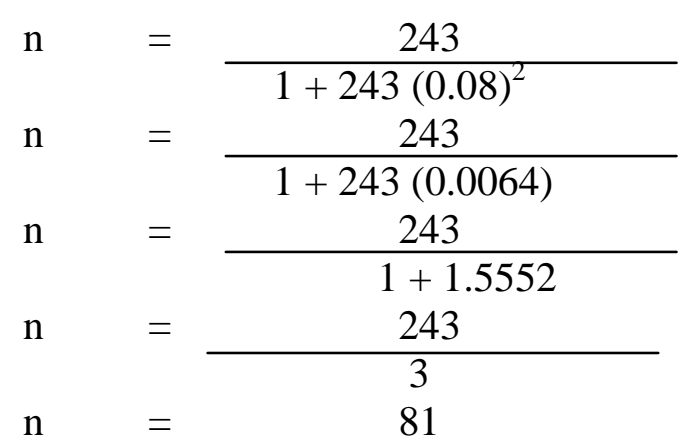

Data for the study was collected through the primary source of data which is majorly 36-item questionnaire titled "Effects of Big Data on the Quality of Audit Reports in Anambra State (EBDQAR)". The questionnaire was structured on a five point likert scale close ended format of Strongly Agree (SA) 5 points, Agree (A) 4 points, Undecided (U) 3 points, Disagree (DA) 2 points, and Strongly disagree (SD) 1 point. The instrument was then administered by 
the researcher on the auditors. The data collected was analyzed using mean statistics while ttest was adopted in testing the hypotheses that guided the study.

The data for the study was collected from the sampled respondents. 85 numbers of questionnaires were administered on the auditors and 80 questionnaires were recovered. This was done with the aid of the researcher and one trained research assistant on how to administer instrument and retrieval of the administered questionnaire from the respondents.

\section{Method of Data Analysis}

Descriptive statistics and correlation matrix were employed alongside the pooled Ordinary Least Square (OLS) regression and the descriptive statistics of our variables. However, to examine the impact relationships between the dependent variables (SAR, TAR, and VAR) and our independent variables and to also test our formulated hypotheses, we used an Ordinary Least Square (OLS) regression analysis.

\section{Proxies for Big Data:}

-Volume of data Collected (Information Overload).

-Frequency of Data Collected (Pattern Recognition) and

-Value of Data Collected (Information Relevance).

\section{Proxies for Quality Audit Reports:}

-Sufficiency of Audit Reports.

-Timeliness of Audit Reports and

-Verifiability of Audit Reports.

\section{Model Specifications}

$\mathrm{X}=$ Independent Variable (Big Data)

$\mathrm{Y}=$ Dependent Variable (Quality of Audit Reports)

$\mathrm{a}=$ Intercept

$E=$ Standard Error of the Estimate

B = Beta Coefficient of the Independent Variable

SAR $=$ sufficiency of Audit Reports

$\mathrm{TAR}=$ Timeliness of Audit Reports

$\mathrm{VAR}=$ Verifiability of Audit Reports

VDC $=$ Volume of Data Collected $\left(\mathrm{X}_{1}\right)$

$\mathrm{FDC}=$ Frequency of Data Collected $\left(\mathrm{X}_{2}\right)$

$\mathrm{VDC}=$ Value of data collected $\left(\mathrm{X}_{3}\right)$

$\mathrm{Y}=\mathrm{F}(\mathrm{X})$ 
Audit Quality $(\mathrm{Y})=\mathrm{F}\left(\mathrm{X}_{1}, \mathrm{X}_{2}, \mathrm{X}_{3}\right)$

This model is modified to three different models so as to achieve the objectives of the study:

MODEL 1:

$\mathrm{SAR}=\mathrm{a}+\mathrm{B}_{1} \mathrm{VDC}+\mathrm{B}_{2} \mathrm{FDC}+\mathrm{B}_{3} \mathrm{VDC}$

MODEL 2:

$\mathrm{TAR}=\mathrm{a}+\mathrm{B}_{1} \mathrm{VDC}+\mathrm{B}_{2} \mathrm{FDC}+\mathrm{B}_{3} \mathrm{VDC}$

MODEL 3:

$\mathrm{VAR}=\mathrm{a}+\mathrm{B}_{1} \mathrm{VDC}+\mathrm{B}_{2} \mathrm{FDC}+\mathrm{B}_{3} \mathrm{VDC}$

MODEL 4:

$\mathrm{VAR}=\mathrm{a}+\mathrm{B}_{1} \mathrm{VDC}+\mathrm{B}_{2} \mathrm{FDC}+\mathrm{B}_{3} \mathrm{VDC}$

MODEL 5:

$\mathrm{VAR}=\mathrm{a}+\mathrm{B}_{1} \mathrm{VDC}+\mathrm{B}_{2} \mathrm{FDC}+\mathrm{B}_{3} \mathrm{VDC}$

\section{DATA PRESENTATION AND ANALYSIS}

\section{Data Presentation}

Table 1: Volume of Data Collected

\begin{tabular}{|l|l|l|l|l|l|l|l|l|}
\hline S/N & $\begin{array}{l}\text { Item Description } \\
\text { SA }\end{array}$ & $\mathbf{A}$ & $\mathbf{U}$ & $\mathbf{D}$ & $\mathbf{S}$ & Mean & $\begin{array}{l}\text { Decis } \\
\text { ion }\end{array}$ \\
\hline 1 & $\begin{array}{l}\text { Volume of data collected made it easy to uncover hidden } \\
\text { patterns in an organization }\end{array}$ & 32 & 26 & 6 & 9 & 7 & 3.8395 & $\begin{array}{l}\text { Accep } \\
\mathrm{t}\end{array}$ \\
\hline 2 & $\begin{array}{l}\text { Volume of data collected helps in record counts for financial } \\
\text { accounts preparation }\end{array}$ & 21 & 47 & 1 & 9 & - & 3.925 & $\begin{array}{l}\text { Accep } \\
\mathrm{t}\end{array}$ \\
\hline 3 & $\begin{array}{l}\text { Volume of data collected helps in providing insights and } \\
\text { approaches in risky business issues to prevent fraud } \\
\text { perpetration. }\end{array}$ & 30 & 25 & 12 & 6 & 4 & $\begin{array}{l}\text { Accep } \\
\mathrm{t}\end{array}$ \\
\hline 4 & $\begin{array}{l}\text { Volume of data collected gives room for comparism of } \\
\text { signatures to confirm proper source of authorized documents. }\end{array}$ & 16 & 40 & 4 & 14 & 5 & 3.775 & $\begin{array}{l}\text { Accep } \\
\mathrm{t}\end{array}$ \\
\hline 5 & $\begin{array}{l}\text { Volume of data collected helps to build large scalable } \\
\text { distributed systems. }\end{array}$ & 12 & 22 & 18 & 20 & 4 & 3.5625 & $\begin{array}{l}\text { Accep } \\
\mathrm{t}\end{array}$ \\
\hline 6 & $\begin{array}{l}\text { Volume of data collected helps in detecting fraudulent, } \\
\text { irregularity or comparable transactions. }\end{array}$ & 42 & 7 & 10 & - & $\begin{array}{l}\text { Accep } \\
\mathrm{t}\end{array}$ \\
\hline
\end{tabular}


Table 2: FREQUENCY OF DATA COLLECTION

\begin{tabular}{|c|c|c|c|c|c|c|c|c|}
\hline $\mathbf{S} / \mathbf{N}$ & Item Description & $\mathbf{S A}$ & $\mathbf{A}$ & $\mathbf{U}$ & D & SD & Mean & Decision \\
\hline 1 & $\begin{array}{l}\text { Frequency of data collected helps to analyze bottlenecks } \\
\text { in the system. }\end{array}$ & 26 & 35 & 8 & 5 & 3 & 3.8375 & Accept \\
\hline 2 & $\begin{array}{l}\text { Frequency of data collected helps in identifying grey } \\
\text { areas where fraud can be perpetuated through proper } \\
\text { monitoring of the rate of receipt of data }\end{array}$ & 18 & 47 & 11 & 1 & & 3.925 & Accept \\
\hline 3 & $\begin{array}{l}\text { Frequency of data gathering helps in building large/small } \\
\text { scale processing system. }\end{array}$ & 11 & 30 & 17 & 11 & 4 & 3.125 & Accept \\
\hline 4 & $\begin{array}{l}\text { Frequency of data collected helps in real time analysis to } \\
\text { monitor situation as it develops. }\end{array}$ & 23 & 32 & 3 & 19 & 1 & 3.6375 & Accept \\
\hline 5 & $\begin{array}{l}\text { Frequency of data collected helps to monitor market } \\
\text { trends }\end{array}$ & 24 & 23 & 17 & 12 & 3 & 3.625 & Accept \\
\hline 6 & $\begin{array}{l}\text { Frequency of data collected helps in finding } \\
\text { unexpected/unknown relationships between different } \\
\text { variables }\end{array}$ & 32 & 25 & 9 & 10 & 2 & 3.8625 & Accept \\
\hline
\end{tabular}

Table 3: VALUE OF DATA COLLECTED

\begin{tabular}{|l|l|l|l|l|l|l|l|l|}
\hline $\mathbf{S} / \mathbf{N}$ & Item Description & SA & $\mathbf{A}$ & $\mathbf{U}$ & $\mathbf{D}$ & $\mathbf{S D}$ & Mean & Decision \\
\hline 1 & $\begin{array}{l}\text { Value of data collected helps to determine the consistence of } \\
\text { transaction processing. }\end{array}$ & 38 & 41 & - & 1 & - & 4.45 & Accept \\
\hline 2 & $\begin{array}{l}\text { Value of data collected helps to maintain and safeguard } \\
\text { government entities. }\end{array}$ & 29 & 42 & 4 & 4 & - & 4.1625 & Accept \\
\hline 3 & $\begin{array}{l}\text { Value of data collected affect the quality of interpretation and } \\
\text { analysis of data transaction in entities. }\end{array}$ & 30 & 26 & 18 & 5 & - & 3.975 & Accept \\
\hline 4 & $\begin{array}{l}\text { Value of data collected helps in identifying customer } \\
\text { preferences. }\end{array}$ & 10 & 35 & 15 & 8 & 10 & 3.1375 & Accept \\
\hline 5 & $\begin{array}{l}\text { Value of data collected helps to ensure that entities comply } \\
\text { with internal policies and other rules guiding their operations } \\
\text { in the State. }\end{array}$ & 16 & 43 & 7 & 10 & 3 & & Accept \\
\hline 6 & $\begin{array}{l}\text { Value of data collected determines the operators' } \\
\text { programming language and statistical tools employed. }\end{array}$ & 17 & 33 & 17 & 11 & - & 3.7 & Accept \\
\hline
\end{tabular}

Table 4: SUFFICIENCY OF AUDIT REPORTS

\begin{tabular}{|l|l|l|l|l|l|l|l|l|}
\hline S/N & Item Description & $\begin{array}{l}\text { S } \\
\mathbf{A}\end{array}$ & $\mathbf{A}$ & $\mathbf{U}$ & $\mathbf{D}$ & $\mathbf{S D}$ & Mean & Decision \\
\hline 1 & Insufficient audit evidence affect the quality of audit work done & 35 & 35 & - & 2 & 3 & 4.025 & Accept \\
\hline 2 & $\begin{array}{l}\text { MDA's sanctioned for refusal and late submission of complete } \\
\text { financial and non financial evidence in Anambra State. S }\end{array}$ & 48 & 19 & 2 & 1 & 3.485 & Accept \\
\hline 3 & $\begin{array}{l}\text { Accountant issue incomplete audit evidences to cover } \\
\text { irregularities, misappropriations and fraud in Anambra State. }\end{array}$ & 8 & 34 & 16 & 7 & 8 & 3.075 & Accept \\
\hline 4 & $\begin{array}{l}\text { Insufficient audit evidences resulted to not updating accounting } \\
\text { and non accounting records in Anambra State. }\end{array}$ & 17 & 34 & 7 & 20 & - & 3.525 & Accept \\
\hline 5 & $\begin{array}{l}\text { Audit evidence presented in a distorted and compromised } \\
\text { manner to confuse the state of affairs of businesses and MDA's } \\
\text { in Anambra State. }\end{array}$ & 11 & 29 & 15 & 10 & 11 & & Accept \\
\hline 6 & $\begin{array}{l}\text { Audit evidence properly documented for ease of reference in } \\
\text { Anambra State. }\end{array}$ & 33 & 28 & 14 & 1 & 1 & 4.025 & Accept \\
\hline
\end{tabular}




\section{Table 5: TIMELINESS OF AUDIT REPORTS}

\begin{tabular}{|l|l|l|l|l|l|l|l|l|}
\hline S/N & Item Description & SA & A & U & D & SD & Mean & Decision \\
\hline 1 & $\begin{array}{l}\text { Time frames set for financial reporting affect project plans } \\
\text { of human and financial resources in Anambra State. }\end{array}$ & 23 & 42 & 9 & 1 & 3 & & Accept \\
\hline 2 & $\begin{array}{l}\text { Financial statements and key performance indicators } \\
\text { supported by reliable working papers submitted for audit } \\
\text { within time frame. }\end{array}$ & 9 & 31 & 12 & 10 & 4 & & Accept \\
\hline 3 & $\begin{array}{l}\text { Auditor size and industry classification risks affect the } \\
\text { timeliness of audit reports in Anambra State. }\end{array}$ & 16 & 27 & 21 & 8 & 4 & 3.9375 & Accept \\
\hline 4 & $\begin{array}{l}\text { Timely auditing and reporting helps to ensure compliance } \\
\text { to rules and correction of anomalies in Anambra State. }\end{array}$ & 36 & 30 & 5 & 5 & 1 & & \\
\hline 5 & $\begin{array}{l}\text { Authorities respond and enforce audit recommendations } \\
\text { timely and accordingly in Anambra State. }\end{array}$ & 13 & 41 & 6 & 10 & 7 & 3.075 & Accept \\
\hline 6 & $\begin{array}{l}\text { Auditors in Anambra State are independent to enable them } \\
\text { issue their reports timely without interference from higher } \\
\text { authorities. }\end{array}$ & 18 & 17 & 11 & 22 & 6 & & Accept \\
\hline
\end{tabular}

\section{Table 6: VERIFIABILITY OF AUDIT REPORTS}

\begin{tabular}{|l|l|l|l|l|l|l|l|l|}
\hline S/N & Item Description & SA & $\mathbf{A}$ & $\mathbf{U}$ & $\mathbf{D}$ & $\begin{array}{l}\text { S } \\
\mathbf{D}\end{array}$ & Mean & Decision \\
\hline 1 & $\begin{array}{l}\text { Audit evidences are presented such that they are easily } \\
\text { verifiable on a test basis in Anambra State. }\end{array}$ & 30 & 40 & 5 & 3 & - & 4.1375 & Accept \\
\hline 2 & $\begin{array}{l}\text { Audit evidence presented helps the auditors in giving a true } \\
\text { and fair opinion on the continuous existence of government } \\
\text { entities in Anambra State }\end{array}$ & 27 & 42 & 5 & 1 & 2 & & Accept \\
\hline 3 & $\begin{array}{l}\text { Verifiability of audit evidence helps the auditors in forming } \\
\text { opinion on the true growth position of government entities in } \\
\text { Anambra State }\end{array}$ & 26 & 43 & 8 & 2 & - & & Accept \\
\hline 4 & $\begin{array}{l}\text { Verifiability of audit evidence helps to verify proper sources } \\
\text { of documents and authorizations. }\end{array}$ & 19 & 46 & 10 & 2 & - & 3.9125 & Accept \\
\hline 5 & $\begin{array}{l}\text { Entities officials are trained on evidenced based transactions } \\
\text { and reporting to enhance verifiability. }\end{array}$ & 16 & 30 & 9 & 14 & 7 & 3.275 & Accept \\
\hline 6 & $\begin{array}{l}\text { Entities authorities deny auditors right of access to their } \\
\text { stocks, records and accounts condition to enhance verifiability. }\end{array}$ & 15 & 29 & 5 & 16 & 13 & 3.1375 & Accept \\
\hline
\end{tabular}


Pooled Ordinary Least Square regression (OLS) results examined the effect of big data on the quality of audit reports in Anambra State and the result obtained is presented below:

Table 7: Quality of Audit Report Regression Result

\begin{tabular}{|l|l|l|l|}
\hline Explanatory Variables & SAR Model & TAR Model & VAR Model \\
\hline VDC & $1.102011\{0.28\}$ & $2.970894\{0.01\}^{* *}$ & $2.659104\{0.01)^{* *}$ \\
VALC & $5.510222\{0.00\}^{*}$ & $3.060545\{0.01\}^{* *}$ & $1.734403\{0.09\}^{* * *}$ \\
\hline R-Squared & $0.240799\{0.80\}$ & $-.761823\{0.09\}^{* * *}$ & $1.564878\{0.13\}$ \\
Adjusted R-Squared & 0.855854 & 0.692430 & 0.825867 \\
F-Statistics & 0.839222 & 0.656941 & 0.805774 \\
Prob(F-Statistics) & 51.45766 & 19.51116 & 41.10365 \\
Dubin Watson & 0.00 & 0.00 & 0.00 \\
\hline
\end{tabular}

\section{SUMMARY OF FINDINGS, CONCLUSION, RECOMMENDATIONS}

\section{Summary of Findings:}

In this study in which we investigated the effect of big data on the quality of audit reports in Anambra State, the regression results for the three models formulated reveal the following findings:

(1) The regression results show that Volume of Data Collection (VDC) effect on the Quality of Audit Report, from the SAR Model, has a positive but insignificant effect on quality of audit report, however, Volume of data collected (VDC) when subjected and verified under a different dependent variables (Timeliness of audit reports, that is TAR model and Verifiability of audit reports, that is VAR models respectively), their results show positive and significant effects on quality of audit report at $5 \%$ respectively.

(2) Similarly, the regression results also show that Frequency of Data Collection (FDC) effect on the Quality of Audit Report, when subjected to the three models formulated (that is SAR Model, TAR model and VAR model), they all show positive and significant effect on quality of audit report in Anambra State.

(3) Finally, the regression results show that Value of Data Collection (VALDC) effect on the Quality of Audit Report from the SAR and VAR Models, have a positive but insignificant effect on quality of audit report but when tested on Timeliness of audit report (TAR), the study shows a negative significant effects on quality of audit reports at $10 \%$.

\section{Conclusion}

Based on the findings of the study, the researcher therefore concludes that, Volume of Data Collection (VDC) has effect on the Quality of Audit Report, from the SAR Model, has a positive but insignificant effect on quality of audit report, ) but has positive and significant effects on quality of audit report at 5\% respectively. However, Frequency of Data Collection (FDC) has effect on the Quality of Audit Report, (that is SAR Model, TAR model and VAR model) have positive and significant effect on quality of audit report in Anambra State. More 
so, effect of the Value of Data Collected (VALDC) on the Verifiability of audit evidence report (VAR), has a positive influence on quality of audit report but this influence is not statistically significant since its p-values is more than 0.10 and Value of Data Collected (VALDC) also has effect on the Quality of Audit Reports from the SAR and TAR Models, ), their results show negative and significant effects on quality of audit report at $10 \%$ and positive but insignificant effect respectively.

\section{Recommendations}

Based on our findings from this study, I therefore recommend the following:

(1) Government External Audit Offices/Supreme Audit Institutions and Auditing Firms that wishes to improve on the quality of their audit report through the use of big data collection, measured as Volume of data collected(VDC) in Anambra State should concentrate more on ensuring that timeliness of the audit report (TAR) as well as verifiability of audit report evidence (VAR) are maintained as these were found to be positively and significantly influencing audit quality and may choose to ignore sufficiency of audit evidence (SAEAR) as this though affects audit quality positively but it is not statistically significant.

(2) Government External Audit Offices/Supreme Audit Institutions and Auditing Firms that wish to improve on the quality of their audit report through the use of big data collection, measured as Frequency of data collected (FDC) in Anambra State should ensure that they maintain high sufficiency of audit reports (SAR), timeliness of their audit report (TAR) and verifiability of their audit report (VAR) as these were found to be positively and significantly influencing audit quality in Anambra State.

(3) Government External Audit Office/ Supreme Audit Institutions and Auditing Firms that wish to improve on the quality of their audit report through the use of big data collection, measured as value of data collected (VALDC) in Anambra State should concentrate more on ensuring that they maintain good timeliness of the audit report as this has a significant negative effect on audit quality but may ignore the use of sufficiency of audit reports (SAR) and verifiability of audit evidence as though they were found to have positive influence, but this influence is statistically insignificant. 


\section{REFERENCES}

\section{REFERENCES}

AB Magazine (2015). Big Data Transforming How Audits Are Carried Out, http://www.accaglobal.com/africa/en/member/member/accountingbusiness/insights/big-data.html

Adeniyi, A. A (2004) Auditing and Investigations. EL- TODA Ventures Limited. American Accounting Association (1972)

Akerlof, G. A. (1970). The market for lemons: Quality uncertainty and the market mechanism. Quarterly Journal of Economics, 84 (3).

Akram Niktaba and Azim Aslani (2015), The effect of audit evidence on auditor's report. International Journal of Accounting Research Vol.2, No.6, 2015, Puublisher: ZARSMI, UAE and Regent Business School, South Africa.

Akter S, Wamba SF, Gunasekaran A, Dubey R, Childe SJ (2016a) How to improve firm performance using big data analytics capability and business strategy alignment? Int J Prod Econ 182:113-131

Alice Ricci \& Foteini Kalyva (2015) "Unlocking the full potential of big data: A change in management approach" http://lup_lub.lu.se/student papers/record/5473712. Lund University Libraries. LUP student papers.

Al-sraheen,dea'a A. omar nawwaf.(2014).The Relationship Between Corporate Governance Mechanisms and Company Attributes and Accounting Conservatism of Jordanian Listed Companies.University Utara Malaysia.

Basu, S., 1997. The conservatism principle and asymmetric timeliness of earnings. Journal of Accounting \& Economics 24, 3-37.

Boyd, D. \& Crawford, K. (2012). Critical questions for big data: Provocations for a cultural, technological, and scholarly phenomenon. Inf. Commun. Soc., 15 (5), 662-679.

Canchu Lin (2016): Exploring Big Data capability: Drivers and Impact On Supply Chain Performance. Journal Of Business Administration Vol.1(2) May, 2016

Chaney, P. \& Philipich, K. (2002). Shredded reputation: the cost of audit failure. Journal of Accounting Research, 40(4), 1221-1245.

Chen, C.L.P. \& Zhang, C.Y., 2014. Data-intensive applications, challenges, techniques and technologies: A survey on Big Data. Information Sciences, 275, pp.314-347.

Christensen, B. E (2016).'Understanding Audit Quality: Insights from Audit Professionals and Investors', Contemporary Accounting Research, 33 (4), 16481684.

Conolly, S. (2012), 7 Key Drivers for the big data Market.Blog Posting, May $14^{\text {th }}$ http://hortonworks.com/blog/7 Key Drivers For The Big Data Market. 
Davenport T.H., Harris (2007) J.G.Competing on analytics: The new science of winning. Harvard Business Press (2007)

Davis, L. R., Soo, B., \& Trompeter, G. (2003). Audit tenure, auditor's independence and earnings management, Working Paper,Boston College.

Defond ML (1992) : The Association Between Changes In Client Firm Agency Cost And Auditor Switching . Journal Of Auditing Practice And Theory 1:1(1):55-67

DeFond, M. \& Zhang, J. (2014). A review of archival auditing research. Journal of Accounting and Economics, 58(2), 275-32

Diamond, D. \& Verrecchia, R. (1991). Disclosure, liquidity and the cost of capital. Journal of Finance, 46 (4), 1325-1359.

Dijiks J.K (2012) “Oracle: Big Data For The Enterprise, 'Oracle White Paper, 2012”

Dumbill E (2013): “ Making Sense Of Big Data” 1(1), 1-2

Ferguson A, Francis J.R, Stockes D.J (2006). What matters in audit pricing: industry specialization or overall market leadership? Accounting and Finance, 46, 97-106.

Francis, J. R. (2004). What do we know about audit quality? British Accounting Review, $36(4), 345-368$

Frank Danielsen and Augustine Franes (2017), "Towards an understanding of big data analytics as a weapon for competitive performance" International Journal On Government Financial Management Vol. XIII No. 2, 2017

George G, Osinga CE, Lavie D, Scott B (2016) Big data and data science methods for management

Gray, G.L., Turner, J.L., Coram, P.J., \& Mock, T.J. (2011). Perceptions and misperceptions regarding the unqualified auditor's report by financial statement preparers, users, and auditors. Accounting Horizons, 25(4), 659-684.

Hoag, M., Myring, M., \& Schroeder, J. (2017). Has Sarbanes-Oxley standardized audit quality?American Journal of Business,32(1), 2-23.

http://talentedge.in/blog/dif Difference Between Big Data And Data Analytics.

http://www.techopedia.com definition of parallel computing.

Jafar Raza Alem, Asma Sajid, Ramzan Talib,Muneeb Niaz (2014) "Review On The Role Of Big Data In Business" International Journal Of Computer Science And Mobile Computing Vol. 3 Issues 4 April 9, 2014, Pg 446-453

Kaplan, Andreas; Haenlein, Michael (2019). "Siri, Siri in my Hand, who's the Fairest in the Land? On the Interpretations, Illustrations and Implications of Artificial Intelligence". Business Horizons. 62: 15-25.

Kaya, I \& Akbulut, D. H (2018): "Big data analytics in financial reporting and 
accounting"PressAcademia Procedia (PAP), V.7, p.256 - 259

Kitchin, Rob; McArdle, Gavin (17 February 2016). "What makes Big Data, Big Data? Exploring the ontological characteristics of 26 datasets". Big Data \& Society. 3 (1): 205395171663113. doi: $10.1177 / 2053951716631130$

Lennox, C. \& Park, C. (2006). The informativeness of earnings and management's issuance of earnings forecasts. Journal of Accounting and Economics, 42 (3), 439-458.

Louis \& Urcan (2015) : Agency Conflicts, Dividend Payout And The Direct Benefits Of Conservative Financial Reporting To Equity Holders. Contemporary Accounting Research 32(2): 455-484

Mayer-Schönberger V., Cukier K (2013).Big data: A revolution that will transform how we live, work, and think .Eamon Dolan/Houghton Mifflin Harcourt, Boston, MA (2013)

McAfee A., Brynjolfsson, E., Davenport, T. H., Patil, D. \& Barton, D. (2012). Big Data: The Management Revolution. Havard Bus Rev, 90 (10), 61-67.

Nataliia Shalimuva and Zoyo Stezhko (2016): Qualitative Characteristics Of The Auditor's Report. IPFA Journal vol.7 No. 4, 2016.

Nyor Terzungwe (2013) Financial Reporting Quality of Nigeria Firms: Users' Perception. International Journal of Business and Social Science Vol. 4 No. 13; October 2013.

Onochie (2002) Arabianybour.com.NG Vol. 1-3

Public Company Accounting Oversight Board (PCAOB). 2010. Release No. 2010-004. Evaluating Audit Results. Auditing Standards No.14 Washington, D.C: PCAOB

PCAOB (2004). Auditing Standard No. 2- An audit of internal control over financial reporting performed in conjunction with an audit of financial statements. Public Company Accounting Oversight Board, Bylaws and Rules - Standards - AS2, March 9, 2004. Procedia -Social and Behavioral Sciences. Elsevier B.V., 145, 4050.

Rajgopal, S., Srinivasan, S., \& Zheng, X. (2015). Measuring Audit Quality.https://www.scheller.gatech.edu/academics/conferences/RajagopalSrinivasan-Zheng.pdfresearch. Acad Manag J 59(5):1493-1507

Salleh, K. \& Jasmani, H. (2014). 'Audit Rotation and Audit Report:Empirical Evidence from Malaysian PLCs over the Period of Ten Years', Procedia - Social and Behavioral Sciences. Elsevier B.V., 145,40-50.

Sharma, R. (2015). Big data and analytics in the audit process. EY Center for Board Matters, Ernst \& Young LLP, on accessed online: https://corpgov.law.harvard.edu/2015/10/24/big-data-and-analytics-in-the-auditprocess/ 
Uthayasankar Sivarajah, Muhammed Mustapha Kamal, Zahir Irani, Weerakkody Vishant. (2017): "Critical Analysis Of Big Data, Challenges And Analytical Methods" Journal of Business Research Vol. 70, Pg 263-286

Vasarhelyi, M.A, Kogan A, \& Tuttle, B.M. (2015) Big Data In Accounting: An Overview:, Accounting Horizons, 29(2), 381-396.

Verrecchia, R. (2001). Essays on disclosure. Journal of Accounting and Economics, 32, $1-3,97-180$.

Wamba SF, Akter S, Edwards A, Chopin G, Gnanzou D (2015) How 'big data' can make big impact: findings from a systematic review and a longitudinal case study. Int $\mathbf{J}$ Prod Econ 165:234-246

Whitehouse, T. (2014). Auditing in the Era of Big Data. http://www.acl.com/pdfs/CW_AuditingintheEraofBigData.pdf

Yin, H. Jiang. Y. Lin. C. Luo, Y. \& Liu. Y. (2014). Big data: transforming the design philosophy of future internet. IEEE Network, 28(4), 14-19.

Yoon, K, Hoogduin, L \& Zhang, L (2015). Big Data As Complementary Audit Evidence, Accounting Horizons, 29(2), 431-438

Zaslavsky A., Perera C., Georgakopoulos D (2012) .Sensing as a service and big data. International Conference on Advances in Cloud Computing (ACC-2012), Bangalore, India (2012), pp. 21-29. View Record in Scopus . 